\title{
SYTUACJA JEZZYKOWA NA UKRAINIE W ŚWIETLE POWSZECHNEGO SPISU LUDNOŚCI ORAZ BADAŃ SOCJOLOGICZNYCH
}

\author{
LANGUAGE SITUATION IN UKRAINE \\ IN LIGHT OF THE GENERAL CENSUS \\ AND SOCIOLOGICAL RESEARCH
}

\begin{abstract}
The article presents the language situation in the independent country of Ukraine. It shows what part of Ukrainian society perceives the Ukrainian language, the Russian language or both of these two languages at the same time as their mother tongue. The paper also shows which of the two languages, Ukrainian or Russian, is more commonly used by Ukrainians in everyday life. Special focus was placed on linguistic diversity of particular regions of Ukraine. The aim of the paper was achieved by analyzing the general census of 2001, as well as the results of the public opinion polls conducted in the period of independence by, among others, the "Public Opinion" Centre for Sociological Research, the Olexander Razumkov Ukrainian Centre for Economic and Political Studies and the Kiev International Institute of Sociology.
\end{abstract}

Key words: language situation; Ukraine; general census; sociological research; Ukrainian language; Russian language

\section{Streszczenie}

W artykule została przybliżona sytuacja językowa w niepodległej Ukrainie. Ukazano dla jakiej części społeczeństwa ukraińskiego językiem ojczystym jest język ukraiński, dla jakiej rosyjski oraz jednocześnie ukraiński i rosyjski. Przybliżono także, którym języ-
PAWEL PIETNOCZKA Uniwersytet Warmińsko-Mazurski, Olsztyn E-mail: pawlopietnoczka@wp.pl

CITATION: Pietnoczka, P. (2018). Sytuacja językowa na Ukrainie w świetle powszechnego spisu ludności oraz badań socjologicznych. Sprawy Narodowościowe. Seria nowa, 2018(50). https://doi.org/10.11649/sn.1671

This work was supported by the author's own resources. No competing interests have been declared.

This is an Open Access article distributed under the terms of the Creative Commons Attribution 3.0 PL License (creativecommons.org/licenses/by/3.0/pl/), which permits redistribution, commercial and non-commercial, provided that the article is properly cited. (C) The Author(s) 2018.

Publisher: Institute of Slavic Studies, Polish Academy of Sciences 
kiem - ukraińskim czy rosyjskim - częściej posługują się w życiu codziennym Ukraińcy. Znaczna uwaga została ponadto zwrócona na zróżnicowanie językowe poszczególnych regionów Ukrainy. Na osiągnięcie postawionego celu pozwoliła analiza wyników spisu powszechnego ludności przeprowadzonego w 2001 r. oraz wyników badań opinii publicznej przeprowadzonych w okresie niepodległości m.in. przez Centrum Badań Socjologicznych „Opinia Społeczna”, Ukraińskie Centrum Badań Ekonomicznych i Politycznych im. Ołeksandra Razumkowa oraz Kijowski Międzynarodowy Instytut Socjologii.

Słowa kluczowe: sytuacja językowa: Ukraina; spis powszechny; badania socjologiczne; język ukraiński; język rosyjski

\section{WPROWADZENIE}

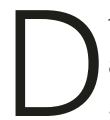

ługa przynależność poszczególnych ziem ukraińskich do państwa rosyjskiego, a następnie radzieckiego, w znacznym stopniu wpłynęła na kształt dzisiejszej struktury narodowościowej oraz sytuacji językowo-kulturowej. W świetle danych z 1897 i 1900 r. w granicach dzisiejszej Ukrainy Rosjanie stanowili 8,1\% mieszkańców (Наулко, 1998, s. 52). Przez kolejne dziesięciolecia odsetek ten zwiększał się, osiągając w 1989 r. 22,1\%¹. Do innych skutków polityki rusyfikacyjnej wobec Ukrainy zalicza się m.in. zmniejszenie odsetka Ukraińców uważających za język ojczysty język ukraiński, zmniejszenie liczby szkół z ukraińskim językiem nauczania oraz liczby książek i periodyków wydawanych w języku ukraińskim, a także ograniczenie nauczania języka i literatury ukraińskiej (Рябчук, 2003, s. 64). Jednym z zagadnień budzących szczególne zainteresowanie na Ukrainie w okresie niepodległości jest kwestia językowa. Niejednokrotnie znajdowała się ona wśród kluczowych problemów podejmowanych podczas poszczególnych kampanii wyborczych - zarówno prezydenckich jak i parlamentarnych. Otóż część sił politycznych - szczególnie lewicowych - domagała się podniesienia statusu języka rosyjskiego poprzez uznanie go za język urzędowy na równi z językiem ukraińskim². Natomiast inne ugrupowania - zwłaszcza prawicowe i centroprawicowe - podkreślały potrzebę zwiększenia obecności języka ukraińskiego we wszystkich sferach życia publicznego.

Celem artykułu jest przybliżenie sytuacji językowej w warunkach niepodległej Ukrainy. Ukazanie dla jakiej części społeczeństwa ukraińskiego językiem ojczystym jest język ukraiński, dla jakiej rosyjski, a także jednocześnie ukraiński i rosyjski. Istotne jest również ukazanie, którym z języków - ukraińskim czy rosyjskim - częściej posługują się mieszkańcy Ukrainy w życiu codziennym. Znaczące będzie ponadto przybliżenie zróżnicowania językowego poszczególnych regionów Ukrainy. W osiągnięciu tego celu pozwoli analiza wyników powszechnego spisu ludności z 2001 r. oraz analiza wyników badań socjologicznych przeprowadzanych w okresie niepodległości m.in. przez Centrum Badań Socjologicznych „Opinia Społeczna”, Ukraińskie Centrum Badań Ekonomicznych i Politycznych im. Ołeksandra Razumkowa oraz Kijowski Międzynarodowy Instytut Socjologii. Powyższe badania uwzględniają sytuację językową na terytorium całej Ukrainy. Zostały one bowiem przeprowadzone w okresie poprzedzającym 2014 r., w którym Rosja naruszyła integralność terytorialną państwa ukraińskiego.

Wzrost udziału ludności rosyjskiej w latach 1959-1989 odbywał się przy jednoczesnym spadku udziału Ukraińców w składzie ogółu ludności Ukrainy z 76,8\% do 72,7\% (Eberhardt, 1994, ss. 188, 243; Заставний, 1993, s. 114).

2 Poza ugrupowaniami lewicowymi, takimi jak Komunistyczna Partia Ukrainy czy Postępowa Socjalistyczna Partia Ukrainy, dużo uwagi potrzebie nadania językowi rosyjskiemu statusu języka urzędowego poświęcała także centrowa Partia Regionów, ciesząca się największym poparciem na wschodzie i południu kraju. 


\section{SYTUACJA JĘZYKOWA W ŚWIETLE POWSZECHNEGO SPISU LUDNOŚCI Z 2001 ROKU}

Po ogłoszeniu niepodległości w 1991 r. na Ukrainie odbył się tylko jeden powszechny spis ludności. Został on przeprowadzony w 2001 r., a dostarczył informacji m.in. na temat struktury narodowościowej oraz językowej Ukrainy. W świetle danych spisu Ukraińcy stanowią 77,8\% mieszkańców Ukrainy, zaś najliczniejszą mniejszość narodową tworzą Rosjanie, którzy stanowią 17,3\% ogółu ludności, zaś wśród mniejszości narodowych i etnicznych aż 79,3\% (Котигоренко, 2014, s. 176; „Про кількість", 2001). Język ukraiński jest językiem ojczystym dla 67,5\% mieszkańców Ukrainy, zaś rosyjski dla 29,6\%. W latach 1989-2001, a więc w okresie pomiędzy ostatnim spisem ludności przeprowadzonym w czasach Związku Radzieckiego i spisem przeprowadzonym w okresie niepodległości Ukrainy, odsetek osób wskazujących język ukraiński jako ojczysty zwiększył się o 2,8\% - z 64,7\% do 67,5\%, zaś osób deklarujących język rosyjski zmniejszył się о 3,2\% - z 32,8\% do 29,6\% („Мовний склад”, 2001; Наулко, 1998, s. 65). Jednak w przypadku osób deklarujących narodowość ukraińską odsetek wskazujących język ukraiński jako ojczysty zmalał z 87,7\% do 85,2\% (Власюк, крисаченко, \& Степико, 2005, s. 192; Наулко, 1998, s. 65). Warto ponadto zaznaczyć, iż wśród Ukraińców, którzy wskazali język ukraiński jako ojczysty, znaczną część stanowili ci, którzy w życiu codziennym posługują się językiem rosyjskim. O dokonanym wyborze przez rosyjskojęzycznych Ukraińców na korzyść języka ukraińskiego miało przesądzić, jak zaznacza Łarysa Masenko, jego "symboliczne powiązanie z ich narodową samoidentyfikacją" (Масенко, 2004).

Język rosyjski jest ojczystym dla 14,8\% osób deklarujących narodowość ukraińską, zaś ukraiński zaledwie dla 0,2\% Rosjan. W porównaniu do Ukraińców jeszcze większej językowej rusyfikacji ulegli przedstawiciele innych grup narodowościowych. Otóż język rosyjski jako ojczysty wskazała większość Greków - 88,5\%, Żydów - 83,0\%, Niemców - 64,7\%, Białorusinów - 62,5\%, Tatarów - 58,7\% i Gruzinów - 54,4\%. Ponadto jest on ojczystym dla wielu Ormian - 43,2\%, Azerów -37,6\%, Bułgarów - 30,3\%, Gagauzów 22,7\% i Mołdawian - 17,6\% (Масенко, 2010, ss. 101-102; "Мовний склад”, 2001). Za jedyną grupę narodową, która uległa znacznej językowej ukrainizacji, należy uznać Polaków. Otóż dla 71\% z nich językiem ojczystym jest język ukraiński, dla 15,6\% rosyjski, zaś dla 12,9\% polski („Мовний склад”, 2001). Dwanaście lat wcześniej poziom rusyfikacji językowej poszczególnych grup narodowościowych wyglądał następująco: język rosyjski jako ojczysty wskazało 78,8\% Greków, Żydów - 90,6\%, Niemców - 67,2\%, Białorusinów - 55,2\%, Tatarów - 49\%, Gruzinów - 42,6\%, Ormian - 47,5\%, Azerów - 24,4\%, Bułgarów - 27,2\%, Gagauzów - 17,2\%, Mołdawian - 15,5\%, Polaków - 20,3\%, Ukraińców - 12,3\% (Baluk, 2002, ss. 28-29; Дністрянський, 2010, s. 208). Tak więc w latach 1989-2001 w przypadku Ukraińców, Greków, Białorusinów, Tatarów, Gruzinów, Azerów, Bułgarów, Gagauzów oraz Mołdawian można zauważyć proces pogłębiania rusyfikacji językowej. Natomiast w przypadku Żydów, Niemców, Ormian i Polaków - przeciwny proces, a mianowicie derusyfikacje językową3.

\section{$\cdots \cdots \cdot$}

Procesowi derusyfikacji językowej Żydów, Niemców, Ormian i Polaków towarzyszyło częstsze wskazywanie przez te grupy narodowościowe języka ukraińskiego jako języka ojczystego. Zob. Дністрянський, 2010, s. 208; „Мовний склад”, 2001. 
Odsetek osób uznających język ukraiński lub rosyjski za ojczysty, podobnie jak w przypadku narodowości, jest silnie zróżnicowany w poszczególnych regionach państwa ${ }^{4}$. Zgodnie z danymi spisu udział ludności deklarującej język ukraiński jako język ojczysty jest największy w regionach zachodniej i centralnej Ukrainy. W jedenastu przewyższa lub dorównuje 90\% - w obwodzie tarnopolskim, iwanofrankiwskim, wołyńskim, rówieńskim, Iwowskim, chmielnickim, winnickim, żytomierskim, czerkaskim, kijowskim i połtawskim. W czterech przekracza 80\% - w obwodzie czernihowskim, kirowogradzkim, sumskim i zakarpackim; w trzech 70\% - w obwodzie czerniowieckim, chersońskim i Kijowie; w dwóch 65\% - w obwodzie mikołajowskim i dniepropietrowskim, zaś w kolejnych dwóch 50\% w obwodzie charkowskim i zaporoskim. W pięciu regionach - w obwodzie odeskim, tugańskim, donieckim, ARK i Sewastopolu - odsetek ludności uznającej język ukraiński za ojczysty nie przekracza 50\%. Jednocześnie w czterech z nich - w Sewastopolu, ARK, obwodzie donieckim i ługańskim - dla większości mieszkańców językiem ojczystym jest język rosyjski („Мовний склад”, 2001). Duży odsetek osób deklarujących język rosyjski jako ojczysty odnotowano również w pozostałych regionach południowo-wschodniej Ukrainy, jednak w żadnym z nich nie przekroczył on $50 \%$ (zob. Tab. 1). Najbliżej osiągnięcia tego progu był obwód zaporoski, w którym język rosyjski jako ojczysty wskazało 48,2\% mieszkańców, zaś najdalej obwód chersoński, w którym rosyjski jest językiem ojczystym dla 24,9\% .

Tabela 1. Język ojczysty $w$ regionach południowo-wschodniej Ukrainy w świetle spisu powszechnego z 2001 roku (w \%)

\begin{tabular}{|l|c|c|}
\hline \multicolumn{1}{|c|}{ Region } & Język ukraiński & Język rosyjski \\
\hline Obwód chersoński & 73,2 & 24,9 \\
\hline Obwód mikołajowski & 69,2 & 29,3 \\
\hline Obwód dniepropietrowski & 67,0 & 32,0 \\
\hline Obwód charkowski & 53,8 & 44,3 \\
\hline Obwód zaporoski & 50,2 & 48,2 \\
\hline Obwód odeski & 46,3 & 41,9 \\
\hline Obwód tugański & 30,0 & 68,8 \\
\hline Obwód doniecki & 24,1 & 74,9 \\
\hline ARK & 10,1 & 77,0 \\
\hline Sewastopol & 6,8 & 90,6 \\
\hline
\end{tabular}

Źr ódło: opracowanie własne na podstawie: „Мовний склад”, 2001.

W latach 1989-2001 w skali Ukrainy odsetek osób uznających język rosyjski za ojczysty zmniejszył się, zaś osób deklarujących język ukraiński wzrósł. Do największych zmian na korzyść języka państwowego doszło w Kijowie (zob. Tab. 2). Otóż w stolicy w omawianym okresie odsetek osób uważających język ukraiński za ojczysty wzrósł o 14,5 punktu procentowego, z 57,6\% do 72,1\%. Natomiast osób deklarujących język rosyjski zmniejszył się z 41,1\% do 25,3\%. Powyższy proces - wzrost liczby ludności uznającej język ukraiński za język ojczysty z jednoczesnym zmniejszaniem się grupy osób deklarujących język rosyjski - nie objął jednak terytorium całego państwa. Otóż w obwodzie donieckim i ługańskim ten proces przebiegał w odwrotnym kierunku. W obwodzie donieckim udział

4 Na temat struktury narodowościowej poszczególnych regionów Ukrainy w świetle spisu powszechnego z 2001 r. zob. np. Pietnoczka, 2016, ss. 194-195; „Про кількість”, 2001. 
osób uznających język ukraiński za język ojczysty zmalał z 30,6\% do 24,1\%, zaś w ługańskim z 34,9\% do 30,0\%. Natomiast odsetek osób deklarujących język rosyjski wzrósł odpowiednio z 67,7\% do 74,9\% i 63,9\% do 68,8\% (zob. Tab. 2). Liczba osób uznających język ukraiński za język ojczysty zmniejszyła się również na Krymie. Otóż w 1989 r. w ówczesnym obwodzie krymskim język ukraiński był ojczystym dla 13,7\% mieszkańców, podczas gdy w 2001 r. dla 10,1\% mieszkańców w przypadku ARK i 6,8\% w przypadku Sewastopola („Мовний склад”, 2001; Наулко, 1998, s. 14) 5 .

Tabela 2. Język ojczysty w poszczególnych regionach Ukrainy w świetle spisów powszechnych z 1989 i 2001 roku (w \%)

\begin{tabular}{|c|c|c|c|}
\hline \multirow{2}{*}{ Region } & \multicolumn{2}{|c|}{ Język ukraiński } & \multirow{2}{*}{$\begin{array}{c}\text { Język rosyjski } \\
1989\end{array}$} \\
\hline & 1989 & 2001 & \\
\hline Obwód tarnopolski & 97,3 & 98,3 & 2,5 \\
\hline Obwód iwanofrankiwski & 94,9 & 97,8 & 4,8 \\
\hline Obwód wołyński & 94,5 & 97,3 & 5,1 \\
\hline Obwód rówieński & 94,0 & 97,0 & 5,6 \\
\hline Obwód Iwowski & 90,1 & 95,3 & 8,8 \\
\hline Obwód chmielnicki & 91,3 & 95,2 & 8,0 \\
\hline Obwód winnicki & 90,7 & 94,8 & 8,6 \\
\hline Obwód żytomierski & 87,2 & 93,0 & 12,0 \\
\hline Obwód czerkaski & 89,1 & 92,5 & 10,3 \\
\hline Obwód kijowski & 88,4 & 92,3 & 10,9 \\
\hline Obwód połtawski & 85,9 & 90,0 & 13,2 \\
\hline Obwód czernihowski & 85,7 & 89,0 & 13,6 \\
\hline Obwód kirowogradzki & 83,3 & 88,9 & 15,1 \\
\hline Obwód sumski & 79,1 & 84,0 & 21,4 \\
\hline Obwód zakarpacki & 78,1 & 81,0 & 5,1 \\
\hline Obwód czerniowiecki & 70,8 & 75,6 & 10,5 \\
\hline Obwód chersoński & 67,7 & 73,2 & 19,4 \\
\hline Kijów & 57,6 & 72,1 & 41,1 \\
\hline Obwód mikołajowski & 64,2 & 69,2 & 33,8 \\
\hline Obwód dniepropietrowski & 61,5 & 67,0 & 37,2 \\
\hline Obwód charkowski & 50,5 & 53,8 & 48,1 \\
\hline Obwód zaporoski & 49,3 & 50,2 & 48.8 \\
\hline Obwód odeski & 41,2 & 46,3 & 47,1 \\
\hline Obwód Ługański & 34,9 & 30,0 & 63,9 \\
\hline Obwód doniecki & 30,6 & 24,1 & 67,7 \\
\hline ARK $^{2}$ & 13,7 & 10,1 & 82,6 \\
\hline
\end{tabular}

${ }^{1}$ Dla 12,7\% mieszkańców obwodu zakarpackiego w świetle spisu ludności z 2001 r. językiem ojczystym jest węgierski, zaś dla 2,6\% rumuński.

${ }^{2}$ W przypadku 1989 r. są to dane dla obwodu krymskiego. Dla 11,4\% mieszkańców ARK w świetle spisu z 2001 r. językiem ojczystym jest krymskotatarski.

Źr ó dło: opracowanie własne na podstawie: Дністрянський, 2010, s. 191; "Мовний склад”, 2001.

5 Warto podkreślić, iż w Sewastopolu w świetle spisu ludności z 2001 r. język rosyjski był językiem ojczystym aż dla 90,6\% mieszkańców. 
Jak wspomniano, największy odsetek osób deklarujących język rosyjski jako ojczysty zamieszkuje w regionach południowo-wschodniej części Ukrainy, a w czterech z nich mieszkańcy uznający język rosyjski za język ojczysty przeważają. Należy jednak jeszcze przy tym odnotować, iż odsetek osób deklarujących język rosyjski jako ojczysty, tak samo zresztą jak w przypadku osób narodowości rosyjskiej, jest wyższy w miastach. Gdy weźmiemy pod uwagę najważniejsze miasta tych regionów, a mianowicie miasta obwodowe oraz stolicę ARK, to zauważymy, że w każdym z nich, z wyjątkiem Chersonia, większość stanowią mieszkańcy wskazujący rosyjski jako język ojczysty (zob. Tab. 3). W trzech z nich - Doniecku, Symferopolu i Ługańsku - ludność deklarująca język rosyjski jako ojczysty przekracza 80\%, w dwóch - Charkowie i Odessie - stanowi ponad 60\%, zaś w trzech Zaporożu, Mikołajowie i Dnieprze ponad 50\%.

Tabela 3. Język ojczysty w stolicy ARK oraz miastach obwodowych południowo-wschodniej Ukrainy w świetle spisu powszechnego z 2001 roku (w \%)

\begin{tabular}{|l|c|c|}
\hline \multicolumn{1}{|c|}{ Miasto } & Język ukraiński & Język rosyjski \\
\hline Chersoń & 53,3 & 45,3 \\
\hline Dniepr (b. Dniepropietrowsk) & 45,9 & 53,1 \\
\hline Mikołajów & 42,2 & 56,8 \\
\hline Zaporoże & 41,6 & 56,8 \\
\hline Charków & 31,8 & 65,9 \\
\hline Odessa & 30,4 & 64,8 \\
\hline Ługańsk & 13,7 & 85,3 \\
\hline Donieck & 11,1 & 87,8 \\
\hline Symferopol & 6,2 & 85,6 \\
\hline
\end{tabular}

1 Dla 6,8\% mieszkańców stolicy ARK językiem ojczystym jest język krymskotatarski.

Źr ód †o: opracowanie własne na podstawie: „Національний склад”, 2001.

W miastach obwodowych pozostałych regionów Ukrainy zdecydowanie przeważa ludność deklarująca język ukraiński. W czterech z nich udział ludności wskazującej język ukraiński jako język ojczysty przekracza 90\% mieszkańców - w Tarnopolu, Łucku, Iwano -Frankiwsku i Równym, w pięciu 80\% - we Lwowie, Chmielnickim, Połtawie, Winnicy i Żytomierzu, zaś w sześciu 70\% - w Kropiwnickim, Czerniowcach, Czerkasach, Użhorodzie, Sumach i Czernihowie (zob. Tab. 4).

Tabela 4. Język ojczysty w miastach obwodowych zachodniej, centralnej i północnej części Ukrainy w świetle spisu powszechnego z 2001 roku (w \%)

\begin{tabular}{|l|c|c|}
\hline \multicolumn{1}{|c|}{ Miasto } & Język ukraiński & Język rosyjski \\
\hline Tarnopol & 94,8 & 3,4 \\
\hline Luck & 92,9 & 6,8 \\
\hline Iwano-Frankiwsk & 92,2 & 1,8 \\
\hline Równe & 92,1 & 7,5 \\
\hline Lwów & 88,5 & 10,0 \\
\hline Chmielnicki & 88,4 & 10,4 \\
\hline Połtawa & 85,4 & 14,1 \\
\hline Winnica & 84,7 & 14,4 \\
\hline
\end{tabular}




\begin{tabular}{|l|c|c|}
\hline Żytomierz & 83,2 & 16,3 \\
\hline Kropiwnicki (b. Kirowograd) & 79,4 & 19,9 \\
\hline Czerniowce & 79,2 & 15,3 \\
\hline Czerkasy & 79,1 & 18,7 \\
\hline Użhorod $^{1}$ & 77,6 & 12,4 \\
\hline Sumy & 77,3 & 20,4 \\
\hline Czernihów & 74,0 & 24,5 \\
\hline
\end{tabular}

${ }^{1}$ Dla 7,03\% mieszkańców Użhoroda językiem ojczystym jest język węgierski.

Źr ódło: opracowanie własne na podstawie: „Національний склад”, 2001.

Spośród tych miast największą różnicę na korzyść języka ukraińskiego odnotowano w Tarnopolu na zachodzie Ukrainy - 94,8\% do 3,4\%, zaś najmniejszą w Czernihowie na północy kraju - 74,01\% do 24,50\% („,Національний склад”, 2001).

\section{SYTUACJA JĘZYKOWA W ŚWIETLE BADAŃ SOCJOLOGICZNYCH}

Wyniki powszechnego spisu ludności z 2001 r. nie ukazują jednak całej złożoności sytuacji językowej na Ukrainie. Otóż ulega ona znacznej zmianie, gdy podczas badań socjologicznych umożliwi się respondentom jednoczesne wskazanie języków ukraińskiego i rosyjskiego jako języka ojczystego. Centrum Badań Socjologicznych „Opinia Społeczna” w wyniku przeprowadzonego w 2006 r. sondażu uzyskało następujące rezultaty: dla 55,5\% mieszkańców Ukrainy językiem ojczystym jest język ukraiński, dla 32\% język rosyjski, zaś dla $11,1 \%$ jednocześnie język ukraiński i rosyjski; 1,4\% respondentów wskazało na inny język („Відповіді”, 2010, s. 358)6. Zbliżone wyniki z przeprowadzonych w tym samym roku badań uzyskało Ukraińskie Centrum Badań Ekonomicznych i Politycznych im. Ołeksandra Razumkowa. Według nich ukraiński jest językiem ojczystym dla 52\% mieszkańców, rosyjski dla 30,7\%, zaś jednocześnie języki ukraiński i rosyjski - dla 15,6\% („Формування”, 2007, ss. 3-4 ${ }^{7}$. Sondaże przeprowadzane przez Centrum Razumkowa w kolejnych latach wskazały na większą liczbę osób deklarujących język ukraiński jako ojczysty oraz zwiększającą się liczbę tych osób, które uznawały jednocześnie oba języki za ojczyste. W 2007 r. język ukraiński był ojczystym dla 51,4\% mieszkańców Ukrainy, rosyjski dla 25,7\%, zaś jednocześnie oba języki dla 21,5\%8. Natomiast według badań z 2008 r. odsetek osób deklarujących język ukraiński jako ojczysty zmniejszył się aż do 43,7\%, w przypadku języka rosyjskiego nieznacznie wzrósł do 26\%, zaś w przypadku jednoczesnego wskazywania ukraińskiego i rosyjskiego zwiększył się aż do 28,7\% („,Яка мова для Вас є рідною?”, 2008) ${ }^{9}$.

Największy odsetek osób uznających za język ojczysty jednocześnie język ukraiński i rosyjski zamieszkuje, podobnie jak w przypadku języka rosyjskiego, na wschodzie i południu kraju. W regionie wschodnim, do którego Centrum Razumkowa zaliczyło obwód

6 Badanie zostało przeprowadzone w okresie od 30 listopada do 7 grudnia 2006 r. na reprezentatywnej grupie 2015 osób, które ukończyły 18. rok życia („Характеристики”, 2010, ss. 340-341).

7 Sondaż został przeprowadzony w okresie od 12 kwietnia do 12 maja 2006 r. na reprezentatywnej grupie 11216 osób, które ukończyły 18. rok życia.

8 Badanie zostało przeprowadzone w okresie od 31 maja do 18 czerwca 2007 r. na reprezentatywnej grupie 10956 respondentów, którzy ukończyli 18. rok życia ("Формування", 2007, ss. 3-4).

9 Badanie zostało przeprowadzone w dniach 7-19 października 2008 r. na reprezentatywnej grupie 10865 respondentów, którzy ukończyli 18. rok życia. 
doniecki, ługański, charkowski, zaporoski i dniepropietrowski, w 2008 r. takiej odpowiedzi udzielało 39\% respondentó $w^{10}$. Natomiast w przypadku regionu południowego, do którego odniesiono obwód odeski, mikołajowski, chersoński i ARK, ten odsetek wyniósł 35,4\%. Ponadto, duża grupa osób deklarujących jednocześnie ukraiński i rosyjski jako ojczysty, w świetle badań Centrum Razumkowa, zamieszkuje w centralnej Ukrainie, gdyż aż 29,1\%. Natomiast niewielki procentowy udział tych osób odnotowano w zachodniej części kraju - zaledwie 4,9\% („Яка мова є для Вас рідною”, 2008). Warto podkreślić, że zwiększenie liczby osób uznających za język ojczysty jednocześnie język ukraiński i rosyjski odbywa się głównie kosztem zmniejszania się liczby osób deklarujących język ukraiński jako ojczysty, co w szczególności widoczne jest w regionie południowym oraz centralnym (zob. Tab. 5).

Tabela 5. Język ojczysty w poszczególnych regionach Ukrainy (w \%)

\begin{tabular}{|l|c|c|c|c|c|c|c|}
\hline \multirow{2}{*}{ Język ojczysty } & \multicolumn{3}{|c|}{ Region południowy } & \multicolumn{3}{c|}{ Region wschodni } & \multicolumn{2}{c|}{ Region centralny } & $\begin{array}{c}\text { Region } \\
\text { zachodni }\end{array}$ \\
\cline { 2 - 8 } & 2006 r. & 2008 r. & 2006 r. & 2008 r. & 2006 r. & 2008 r. & 2006 r. \\
\hline Ukraiński & 27,7 & 13,9 & 21,3 & 15,2 & 72,0 & 59,6 & 90,3 \\
\hline Rosyjski & 52,0 & 48,0 & 54,0 & 44,4 & 13,0 & 10,1 & 3,8 \\
\hline Ukraiński i rosyjski & 17,0 & 35,4 & 23,5 & 39,0 & 14,3 & 29,1 & 3,3 \\
\hline
\end{tabular}

Źr ó d †o: opracowanie własne na podstawie: „Яка мова є для Вас рідною", 2008.

Korzystniejsza sytuacja języka ukraińskiego w porównaniu z badaniami przeprowadzonymi przez Centrum Razumkowa w 2008 r. wyłania się z wyników badań przeprowadzonych w marcu 2013 r. w ramach projektu międzynarodowego „Region, naród i więcej. Interdyscyplinarna i transkulturowa rekonceptualizacja Ukrainy". Otóż zgodnie z nimi język ukraiński jest językiem ojczystym dla 50,9\% mieszkańców Ukrainy, język rosyjski dla 21,2\%, zaś jednocześnie ukraiński i rosyjski dla 23,2\% (Бестерс-Дільґер, 2014, s. 71). Język ukraiński jest ojczystym dla większości mieszkańców w osiemnastu regionach, w czterech najwięcej zadeklarowało język rosyjski, zaś aż w pięciu większość wskazała jednocześnie język ukraiński i język rosyjski. W świetle tych badań udział ludności deklarującej język ukraiński jako ojczysty przewyższa 90\% w pięciu regionach - w obwodzie iwanofrankiwskim, tarnopolskim, Iwowskim, rówieńskim i wołyńskim ${ }^{11}$. W sześciu regionach przekracza $80 \%$ - w obwodzie winnickim, zakarpackim, chmielnickim, kijowskim, żytomierskim i czerkaskim, w trzech $60 \%$ - w obwodzie połtawskim, Kijowie i obwodzie czerniowieckim, w jednym 50\% - w obwodzie sumskim. Natomiast w obwodzie czernihowskim wynosi niespełna 50\%. Zgodnie z wynikami badań język rosyjski jest językiem ojczystym dla większości mieszkańców Sewastopola, ARK, obwodu ługańskiego i donieckiego, zaś jednocześnie język ukraiński i rosyjski dla mieszkańców obwodu kirowogradzkiego, zaporoskiego, charkowskiego, mikołajowskiego i odeskiego. Ponadto bardzo duży udział osób (powyżej 30\%) uznających za język ojczysty jednocześnie ukraiński i rosyjski zamieszkuje w obwodzie donieckim, sumskim, ługańskim, chersońskim i dniepropietrowskim (zob. Tab. 6).

10 Według badań przeprowadzonych przez Centrum Badań Socjologicznych "Opinia Społeczna“ dwa lata wcześniej, odsetek mieszkańców deklarujących jednocześnie język ukraiński i rosyjski w regionie wschodnim wynosit 15,0\%, zaś południowym - 11,8\%. Zob. Масенко, 2010, ss. 104-105.

11 W świetle spisu powszechnego z 2001 r. takich regionów było aż dziesięć. 
Tabela 6. Odsetek mieszkańców poszczególnych regionów Ukrainy uznających za język ojczysty język ukraiński, język rosyjski lub jednocześnie język ukraiński i język rosyjski

\begin{tabular}{|c|c|c|}
\hline \multirow[t]{2}{*}{ Region } & \multicolumn{2}{|c|}{ Odsetek mieszkańców uznających za język ojczysty } \\
\hline & ukraiński & rosyjski \\
\hline Obwód iwanofrankiwski & 98,9 & 0,6 \\
\hline Obwód tarnopolski & 97,9 & 0,7 \\
\hline Obwód Iwowski & 96,1 & 1,8 \\
\hline Obwód rówieński & 93,8 & 0,7 \\
\hline Obwód wołyński & 93,1 & 0,8 \\
\hline Obwód winnicki & 88,9 & 5,6 \\
\hline Obwód zakarpacki & 88,8 & 1,3 \\
\hline Obwód chmielnicki & 86,6 & 1,1 \\
\hline Obwód kijowski & 83,5 & 4,5 \\
\hline Obwód żytomierski & 83,3 & 2,4 \\
\hline Obwód czerkaski & 82,8 & 5,2 \\
\hline Obwód połtawski & 69,5 & 11,5 \\
\hline Kijów & 66,3 & 9,2 \\
\hline Obwód czerniowiecki & 60,7 & 5,1 \\
\hline Obwód sumski & 52,6 & 5,1 \\
\hline Obwód czernihowski & 49,0 & 4,7 \\
\hline Obwód chersoński & 46,5 & 16,0 \\
\hline Obwód dniepropietrowski & 39,8 & 26,2 \\
\hline Obwód kirowogradzki & 38,2 & 6,1 \\
\hline Obwód odeski & 20,8 & 29,4 \\
\hline Obwód mikołajowski & 18,2 & 38,3 \\
\hline Obwód zaporoski & 18,1 & 30,5 \\
\hline Obwód charkowski & 16,8 & 37,5 \\
\hline Obwód doniecki & 10,9 & 47,7 \\
\hline ARK & 7,8 & 65,9 \\
\hline Obwód ługański & 4,0 & 53,6 \\
\hline Sewastopol & 2,0 & 86,3 \\
\hline Łącznie & 50,9 & 21,2 \\
\hline
\end{tabular}

Źr ó dło: Бестерс-Дільґер, 2014, s. 71.

Na znaczny wpływ języka rosyjskiego na Ukrainie wskazują również wyniki badań przeprowadzonych przez Centrum Badań Socjologicznych „Opinia Społeczna” w 2006 r., podczas których respondenci podawali, którym językiem posługują się w życiu codziennym. Z uzyskanych przez ośrodek rezultatów wynika, że największa grupa badanych, bo aż 40,3\% w życiu codziennym posługuje się językiem rosyjskim (25,2\% wyłącznie, 15,1\% najczęściej), 35,3\% w języku ukraińskim (22,4\% wyłącznie, 12,9\% najczęściej), zaś 20,4\% w równym stopniu w języku ukraińskim i rosyjskim (Масенко, 2010, s. 105) ${ }^{12}$. W świetle powyższych badań w regionie wschodnim, do którego zaliczono obwód doniecki, ługański, charkowski, zaporoski i dniepropietrowski, językiem rosyjskim w życiu

12 Ponadto 3,1\% wskazało na surżyk, zaś 0,9\% na inne języki. 
codziennym posługuje się 69,8\% mieszkańców (43,9\% wyłącznie, 25,9\% najczęściej), w równym stopniu językiem ukraińskim i rosyjskim 21,6\%, natomiast językiem ukraińskim tylko 5,2\% (1,5\% wyłącznie, 3,7\% najczęściej). W regionie południowym - obejmującym obwody odeski, chersoński, mikołajowski, ARK i Sewastopol - uzyskano następujące wyniki: 63,1\% wskazało język rosyjski (odpowiednio 49\% i 14,1\%), 17,1\% język ukraiński i rosyjski, zaś 16,5\% język ukraiński (6,3\% i 10,2\%). Na zachodniej Ukrainie oraz w centrum większość mieszkańców posługuje się w życiu codziennym językiem ukraińskim, zaś na północy kraju wartości dla obu języków są bardzo zbliżone (zob. Tab. 7) ${ }^{13}$.

Tabela 7. Język, którym mieszkańcy poszczególnych regionów Ukrainy posługują się w życiu codziennym (w \%)

\begin{tabular}{|l|c|c|c|c|c|}
\hline Komunikowanie się: & Zachód & Centrum & Północ & Wschód & Południe \\
\hline Wyłącznie w języku rosyjskim & 0,8 & 3,0 & 14,0 & 43,9 & 49,0 \\
\hline $\begin{array}{l}\text { W większości sytuacji w języku } \\
\text { rosyjskim }\end{array}$ & 1,9 & 8,0 & 15,1 & 25,9 & 14,1 \\
\hline Wyłącznie w języku ukraińskim & 64,8 & 43,3 & 13,4 & 1,5 & 6,3 \\
\hline $\begin{array}{l}\text { W wiékszości sytuacji w języku } \\
\text { ukraińskim }\end{array}$ & 22,8 & 22,3 & 14,2 & 3,7 & 10,2 \\
\hline $\begin{array}{l}\text { W równej mierze w języku } \\
\text { ukraińskim i rosyjskim }\end{array}$ & 5,0 & 19,7 & 38,2 & 21,6 & 17,1 \\
\hline Surżykiem & 1,6 & 3,7 & 4,3 & 3,4 & 2,3 \\
\hline Innym językiem & 3,2 & 0,0 & 0,9 & 0,0 & 1,0 \\
\hline
\end{tabular}

Źródto: Масенко, 2010, s. 106.

Na dominację języka rosyjskiego na wschodzie i południu kraju wskazuje również Kijowski Międzynarodowy Instytut Socjologii. Z badań przeprowadzonych przez ten ośrodek wynika, iż we wschodnim regionie kraju, do którego odniesiono obwód doniecki, tugański i charkowski - aż 92,3\% badanych łatwiej jest posługiwać się językiem rosyjskim, zaś tylko 7,7\% ukraińskim ${ }^{14}$. Dla południowego regionu - obwód odeski, mikołajowski, chersoński, zaporoski i ARK - te wartości wynoszą odpowiednio 84,5\% i 15,5\%. Ponadto przewage język rosyjski zyskał w regionie wschodnio-centralnym - obwód dniepropietrowski, połtawski, sumski i czernihowski - w którym łatwiej posługuje się rosyjskim 59,3\% mieszkańców, zaś ukraińskim 40,7\%. Język ukraiński dominuje natomiast w regionie zachodnim - obwód wołyński, rówieński, Iwowski, iwanofrankiwski, tarnopolski, zakarpacki i czerniowiecki, a także w zachodnio-centralnym - obwód chmielnicki, żytomierski, winnicki, kirowogradzki, czerkaski, kijowski oraz Kijów. W pierwszym z wymienionych regionów łatwiej jest posługiwać się językiem ukraińskim 95\% mieszkańców, zaś rosyjskim 5\%. Dla drugiego regionu te wartości wynoszą odpowiednio 74,4\% і 25,6\% (Хмелько, 2017, s. 11).

13 Centrum Badań Socjologicznych „Opinia Społeczna” do regionu zachodniego zaliczyło obwód wołyński, rówieński, Iwowski, tarnopolski, iwanofrankiwski, zakarpacki i czerniowiecki; centralnego - obwód chmielnicki, winnicki, czerkaski, połtawski i kirowogradzki; zaś północnego - obwód żytomierski, kijowski, czernihowski, sumski i Kijów („Характеристики”, 2010, s. 343).

14 Są to połączone wyniki ośmiu badań przeprowadzonych w okresie od lutego do października 2003 r. na reprezentatywnej grupie 22462 osób, które ukończyły 18. rok życia. 
Wyniki powszechnego spisu ludności przeprowadzonego w 2001 r. ukazały znaczny stopień zrusyfikowania społeczeństwa ukraińskiego. Prawie 30\% mieszkańców zadeklarowało język rosyjski jako język ojczysty. Należy zaznaczyć, iż w latach 1989-2001 udział ludności wskazującej rosyjski jako ojczysty uległ pewnemu zmniejszeniu, zaś osób deklarujących ukraiński zwiększeniu. Ten proces ukrainizacji językowej nie objął jednak terytorium całego państwa. W Donbasie, co warto podkreślić, nawet w warunkach niepodległości Ukrainy, następowała dalsza rusyfikacja językowa. Na to wskazuje większy odsetek osób deklarujących język rosyjski jako ojczysty podczas spisu ludności w 2001 r. w porównaniu z wynikami spisu z 1989 r. Poza Donbasem jedynym regionem, w którym zmniejszył się udział ludności deklarującej ukraiński jako ojczysty jest Krym. W tym przypadku jednocześnie zmalał udział mieszkańców wskazujących jako ojczysty język rosyjski. Te zmiany językowe na Krymie były głównie podyktowane powrotem na półwysep Tatarów krymskich. Wyniki spisu ukazały bardzo duże zróżnicowanie językowe poszczególnych regionów Ukrainy. W sześciu regionach zachodniej Ukrainy - obwodach tarnopolskim, iwanofrankiwskim, wołyńskim, rówieńskim, Iwowskim i chmielnickim - odsetek osób deklarujących ukraiński jako ojczysty przekroczył 95\%, podczas gdy w Sewastopolu wynióst niespełna 7\%, w ARK nieco ponad 10\%, w obwodzie donieckim ok. 24\%, zaś ługańskim 30\%.

Złożoność sytuacji językowej na Ukrainie jeszcze bardziej ukazują wyniki badań socjologicznych. Okazuje się, że znaczna część społeczeństwa deklaruje jako język ojczysty jednocześnie ukraiński i rosyjski. Takich deklaracji podczas badań opinii publicznej, podobnie jak w przypadku języka rosyjskiego najwięcej odnotowano w południowo-wschodniej części Ukrainy. Mieszkańcy wskazujący jako język ojczysty jednocześnie ukraiński i rosyjski stanowią większość aż w pięciu regionach - obwodach kirowogradzkim, zaporoskim, charkowskim, mikołajowskim i odeskim. Należy zaznaczyć, iż wzrost udziału ludności określającej oba języki jako ojczyste odbywa się głównie kosztem zmniejszenia odsetka osób deklarujących wyłącznie język ukraiński. Na bardzo duże wpływy języka rosyjskiego na Ukrainie, a szczególnie na jego dominację na wschodzie i południu kraju, wskazały wyniki badań socjologicznych, podczas których respondenci mieli zadeklarować którym językiem łatwiej jest się im posługiwać. Warto na koniec podkreślić, iż w świetle przytoczonych badań KMIS, w przypadku regionu wschodniego łatwiej jest się posługiwać językiem rosyjskim ponad 92\%, zaś w regionie południowym ok. 85\% mieszkańców. Natomiast na terenie zachodniej Ukrainy niekwestionowaną przewage ma język ukraiński, którym łatwiej jest się posługiwać 95\% mieszkańców. Przewage język urzędowy posiada również w regionie zachodnio-centralnym, w którym łatwość posługiwania się nim zadeklarowało ponad $74 \%$ mieszkańców.

\section{BIBLIOGRAFIA}

Baluk, W. (2002). Koncepcje polityki narodowościowej Ukrainy: Tradycje i współczesność. Wrocław: Wydawnictwo Uniwersytetu Wrocławskiego.

Eberhardt, P. (1994). Przemiany narodowościowe na Ukrainie XX wieku. Warszawa: Obóz. 
Pietnoczka, P. (2016). Mniejszość i większość na pograniczu ukraińsko-rosyjskim. W P. Pietnoczka, M. Radoch, \& D. Szweda (Red.), Mniejszość i większość: Relacje kulturowe na pograniczach (Cz. 1, ss. 207-217). Olsztyn: Instytut Historii i Stosunków Międzynarodowych UWM w Olsztynie.

Бестерс-Дільґер, Ю. (2014). Українська, російська та англійська мови у сприйнятті українців (на матеріалі всеукраїнського опитування 2013 року). Українське мовознавство: Збірник наукових праць, 1(44), 69-81.

Відповіді респондентів на запитання анкети (одномірний розподіл, \%). (2010). W Ю. Бестерс-Дільґер (Red.), Мовна політика та мовна ситуація в Україні: Аналіз і рекомендації (ss. 344-363). Київ: Видавничий дім „Києво-Могилянська академія”.

Власюк, О., Крисаченко, В., \& Степико, М. (2005). Український сочіум. Київ: Знання України.

Дністрянський, М. (2010). Політична географія та геополітика України. Тернопіль: Навчальна книга - Богдан.

Заставний, Ф. (1993). Населення України: До 125-річчя „Просвіти”. Львів: МП „Край”, Товариство української мови ім. Тараса Шевченка „Просвіта”.

Котигоренко, В. (Red.). (2014). Донбас в етнополітичному вимірі. Київ: ІПіЕНД ім. І. Ф. Кураса НАН України.

Масенко, Л. (2004). Мовна ситуація України. Незалежний культурологічний часопис „ї", 2004(35). Pobrano 29 listopada 2017, z http://www.ji.Iviv.ua/n35texts/masenko-mov_ syt.htm

Масенко, Л. (2010). Мовна ситуація України: Соціолінгвістичний аналіз. W Ю. БестерсДільґер (Red.), Мовна політика та мовна ситуація в Україні: Аналіз і рекомендації (ss. 96-131). Київ: Видавничий дім „Києво-Могилянська академія”.

Мовний склад населення України за даними Всеукраїнського перепису населення. (2001). Pobrano 5 października 2017, z http://2001.ukrcensus.gov.ua/results/general/language/ Наулко, В. (1998). Хто і від коли живе в Україні. Київ: Головна спеціалізована редакція літератури мовами національних меншин України.

Національний склад населення, мовні ознаки, громадянство. (2001). Pobrano 8 września 2015, z http://database.ukrcensus.gov.ua/MULT/Database/Census/databasetree_uk.asp

Про кількість та склад населення України за підсумками Всеукраїнського перепису населення 2001 року. (2001). Pobrano 1 września 2015, z http://2001.ukrcensus.gov.ua/results/ general/nationality/

Рябчук, М. (2003). Дві України: Реальні межі, віртуальні війни. Київ: Критика.

Формування спільної ідентичності громадян України: Перспективи і виклики. (2007). Національна оборона і безпека, 9(93), 2-27.

Характеристики масового опитування населення України. (2010). W Ю. Бестерс-Дільґер (Red.), Мовна політика та мовна ситуація в Україні: Аналіз і рекомендації (ss. 340 343). Київ: Видавничий дім „Києво-Могилянська академія".

Хмелько, В. (2015). Лінгво-етнічна структура України: Регіональні особливості та тенденції змін за роки незалежності. Pobrano 29 listopada 2017, z http://www.kiis.com.ua/materials/articles_HVE/16_linguaethnical.pdf

Яка мова для Вас є рідною? (динаміка, 2006- 2008). (2008). Pobrano 10 września 2015, z http://www.razumkov.org.ua/ukr/poll.php?poll_id=290

Яка мова є для Вас рідною (регіональний розподіл, динаміка 2006-2008). (2008). Pobrano 10 września 2015, z http://www.razumkov.org.ua/ukr/poll.php?poll_id=436 
Baluk, W. (2002). Koncepcje polityki narodowościowej Ukrainy: Tradycje i wspótczesność. Wrocław: Wydawnictwo Uniwersytetu Wrocławskiego.

Besters-Dil'ger, I. (2014). Ukraïns'ka, rosiīs'ka ta anhliīs'ka movy u spryīniatti ukraïntsiv (na materiali vseukraïns'koho opytuvannia 2013 roku). Ukraïns'ke movoznavstvo: Zbirnyk naukovykh prats', 1(44), 69-81.

Dnistrians'kyıॅ, M. (2010). Politychna heohrafiia ta heopolityka Ukraïny. Ternopil': Navchal'na knyha - Bohdan.

Eberhardt, P. (1994). Przemiany narodowościowe na Ukrainie XX wieku. Warszawa: Obóz.

Formuvannia spil'noï identychnosti hromadian Ukraïny: Perspektyvy i vyklyky. (2007). Natsional'na oborona i bezpeka, 9(93), 2-27.

IAka mova dlia Vas e ridnoiu? (dynamika, 2006- 2008). (2008). Retrieved September 10, 2015, from http://www.razumkov.org.ua/ukr/poll.php?poll_id=290

IAka mova e dlia Vas ridnoiu (rehional'nyĭ rozpodil, dynamika 2006-2008). (2008). Retrieved September 10, 2015, from http://www.razumkov.org.ua/ukr/poll.php?poll_id=436

Kharakterystyky masovoho opytuvannia naselennia Ukraïny. (2010). In I. Besters-Dil'ger (Ed.), Movna polityka ta movna sytuatsiia v Ukraïni: Analiz i rekomendatsiï (pp. 340343). Kyïv: Vydavnychyĭ dim "Kyievo-Mohylians'ka akademiia".

Khmel'ko, V. (2015). Linhvo-etnichna struktura Ukraïny: Rehional'ni osoblyvosti ta tendentsiï zmin za roky nezalezhnosti. Retrieved November 29, 2017, from http://www.kiis.com. ua/materials/articles_HVE/16_linguaethnical.pdf

Kotyhorenko, V. (Ed.). (2014). Donbas v etnopolitychnomu vymiri. Kyïv: IPiEND im. I. F. Kurasa NAN Ukraïny.

Masenko, L. (2004). Movna sytuatsiia Ukraïny. Nezalezhnyĭ kul'turolohichnyĭ chasopis "ï", 2004(35). Retrieved November 29, 2017, from http://www.ji.Iviv.ua/n35texts/masenko -mov_syt.htm

Masenko, L. (2010). Movna sytuatsiia Ukraïny: Sotsiolinhvistychnyĭ analiz. In I. BestersDil'ger (Ed.), Movna polityka ta movna sytuatsiia v Ukraïni: Analiz i rekomendatsiï (pp. 96-131). Kyïv: Vydavnychy̆ dim "Kyievo-Mohylians'ka akademiia".

Movnyĭ sklad naselennia Ukraïny za danymy Vseukraïns'koho perepysu naselennia. (2001). Retrieved October 5, 2017, from http://2001.ukrcensus.gov.ua/results/general/ language/

Natsional'nyı̆ sklad naselennia, movni oznaky, hromadianstvo. (2001). Retrieved September 8, 2015, from http://database.ukrcensus.gov.ua/MULT/Database/Census/databasetree_uk.asp

Naulko, V. (1998). Khto i vid koly zhyve v Ukraïni. Kyïv: Holovna spetsializovana redaktsiia literatury movamy natsional'nykh menshyn Ukraïny.

Pietnoczka, P. (2016). Mniejszość i większość na pograniczu ukraińsko-rosyjskim. In P. Pietnoczka, M. Radoch, \& D. Szweda (Eds.), Mniejszość i większość: Relacje kulturowe na pograniczach (Pt. 1, pp. 207-217). Olsztyn: Instytut Historii i Stosunków Międzynarodowych UWM w Olsztynie.

Pro kil'kist' ta sklad naselennia Ukraïny za pidsumkamy Vseukraïns'koho perepysu naseIennia 2001 roku. (2001). Retrieved September 1, 2015, from http://2001.ukrcensus. gov.ua/results/general/nationality/

Riabchuk, M. (2003). Dvi Ukraïny: Real'ni mezhi, virtual'ni viinny. Kyïv: Krytyka. 
Vidpovidi respondentiv na zapytannia ankety (odnomirnyı̆ rozpodil, \%). (2010). In I. Besters -Dil'ger (Ed.), Movna polityka ta movna sytuatsiia v Ukraïni: Analiz i rekomendatsiï (pp. 344-363). Kyïv: Vydavnychyı̆ dim "Kyievo-Mohylians'ka akademiia”.

Vlasiuk, O., Krysachenko, V., \& Stepyko, M. (2005). Ukraïns'kyı̆ sotsium. Kyïv: Znannia Ukraïny.

Zastavnyı̆, F. (1993). Naselennia Ukraïny: Do 125-richchia "Prosvity". L'viv: MP "Kraĭ", Tovarystvo ukraïns'koï movy im. Tarasa Shevchenka "Prosvita". 